\title{
+17 C/G POLYMORPHISM IN MATRIX METALLOPROTEINASE (MMP)-8 GENE AND ITS ASSOCIATION WITH PERIODONTITIS
}

\author{
Hastinefia Putri', Benso Sulijaya² , Bambang Tri Hartomo ${ }^{1}$, Antonius Winoto Suhartono ${ }^{1}$, Elza Ibrahim Auerkari' \\ 'Department of Oral Biology, Faculty of Dentistry, Universitas Indonesia, Jakarta, Indonesia \\ ${ }^{2}$ Department of Periodontology, Faculty of Dentistry, Universitas Indonesia, Jakarta, Indonesia
}

\begin{abstract}
InTRODUCTION: Matrix metalloproteinase-8 (MMP-8), encoded by MMP-8 gene (chromosomal location, 11q22.3), is a proteolytic enzyme that is involved in the pathogenesis of periodontitis. Polymorphism of the encoding MMP- 8 gene can affect the risk of the disease.

ОвјеCтIVEs: This study aimed to evaluate the relationship between $+17 \mathrm{C} / \mathrm{G}$ polymorphism in $M M P-8$ and periodontitis in an Indonesian sample population.

MATERIAL AND METhods: Polymerase chain reaction-restriction fragment length polymorphism (PCR-RFLP) analysis of the $+17 \mathrm{C} / \mathrm{G}$ polymorphism in $M M P-8$ was conducted in stored genomic DNA samples from 100 subjects with periodontitis and 100 healthy controls. Patients were examined in a previous study by a periodontics and diagnosed as periodontitis based on anamnesis and clinical examination (periodontal pocket depth $\geq 4 \mathrm{~mm}$ and the presence of clinical attachment loss.

RESULTS: The frequencies of the genotypes or alleles in the periodontitis and control groups were not significantly different (genotype, $p=0.283$; alleles, $p=0.11$ ). Any remaining trend toward higher frequencies of the polymorphic genotypes or alleles in the periodontitis group was explained by the adjustment for age.

ConcLusions: The results showed no significant association between the $+17 \mathrm{C} / \mathrm{G}$ polymorphism in $M M P-8$ and the risk of periodontitis in the Indonesian population. No change in the significance is expected even with a considerably larger sample.
\end{abstract}

KEY WORDS: MMP-8, periodontitis, gene polymorphism, +17 C/G polymorphism.

J Stoma 2020; 73, 4: 154-158

DOI: https://doi.org/10.5114/jos.2020.98310

\section{INTRODUCTION}

Periodontitis is a common inflammatory disease that results in a progressive destruction of the periodontal ligament, following in loss of alveolar bone and teeth during the final untreated stages. About half or more of the adult population in the world is affected by periodontitis, and the prevalence is increasing with age, unhealthy diet, smoking habits, and poor oral hy- giene [1-3]. It is the most common (61\%) disease affecting the general population in Indonesia [4].

Periodontitis is a multifactorial disease, thought to be initiated via gingival and periodontal inflammation, which is promoted by anaerobic bacterial pathogens such as Porphyromonasgingivalis, Tannerella forsythia, Treponema denticola, Fusobacterium nucleatum, and/or Aggregatibacter actinomycetem comitans [5]. The pres-
JOURNAL OF STOMATOLOGY CZASOPISMO STOMATOLOGICZNE
Address for Correspondence: Prof. Dr. Elza I Auerkari, MS, SpOF(K), Department of Oral Biology, Faculty of Dentistry, Universitas Indonesia, Jl. Salemba Raya No. 4, Jakarta 10430, Indonesia, phone/fax: + 6281284392420 , e-mail: elza.ibrahim@ui.ac.id

ReCEIVED: 09.04.2020 • ACCEPTED: 13.06.2020 • PUBlished: 30.06.2020 


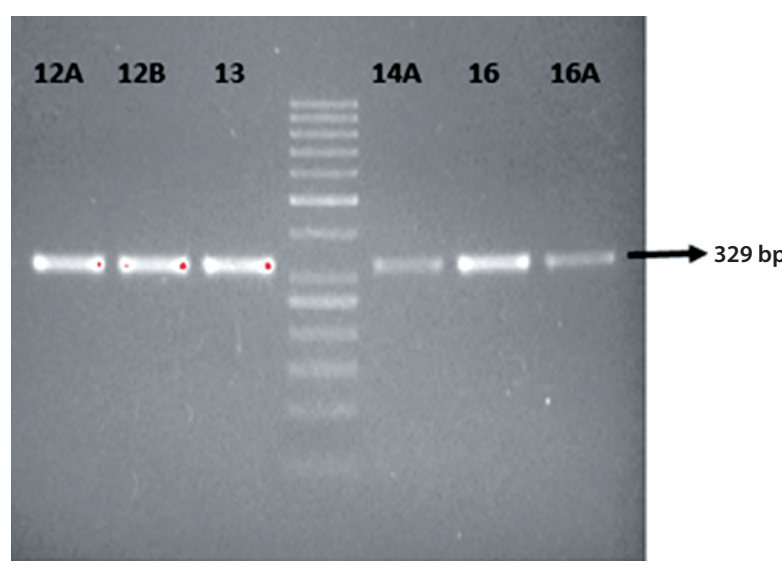

FIGURE 1. Examples of the visualized $P C R$ products from sample numbers 12A, 12B, 13, 14A, 16, and 16A

ence of bacteria and bacterial biofilms is, however, not sufficient for the destruction of periodontal tissues, and the extent of bacterial accumulation is poorly correlated with the risk or severity of periodontitis [6]. The individual outcome will strongly depend on the host immune responses, which are related to factors, such as genetic predisposition [6-8]. One of the implicated genes in the pathogenesis of periodontitis is $M M P-8$ (chromosomal location, 11q22.3), which encodes a proteolytic matrix metalloproteinase enzyme (MMP) that regulates the repair and breakdown of the connective tissue [9-11]. In inflammation, elevated levels of MMP-8 are found in the periodontal tissues, gingival crevicular fluid (GCF), and saliva resulting in the degradation of extracellular matrix, which contains type-1 collagen, a major component of periodontal tissues. MMP- 8 is produced by infiltrating inflammatory cells, such as neutrophils, plasma cells, and macrophages. In addition, it is produced by resident cells, including gingival fibroblasts and epithelial cells [9-11].

The functional variation in the expression of regulatory genes is commonly due to single nucleotide polymorphisms (SNP), and polymorphisms of MMP-8 (Figure 1) could be related to the risk of periodontitis by modification of the innate and adaptive immune responses [12, 13]. Significant associations between periodontitis and the $-799 \mathrm{C} / \mathrm{T}$ (rs11225395) polymorphism of MMP-8 have been reported [14-16]. Another known SNP occurs at $+17 \mathrm{C} / \mathrm{G}$ (rs2155052) in the first exon [12]. There is limited information about the effect of this polymorphism on periodontal disease [14, 15], with none in Indonesia.

\section{OBJECTIVES}

This study aimed to address the impact of this polymorphism on the risk of periodontitis in the Indonesian population.
TABLE 1. Demographic and clinical data of the periodontitis and control groups

\begin{tabular}{|l|c|c|}
\hline Parameter & Periodontitis & Control \\
\hline Age range & $25-65$ & $19-61$ \\
\hline Mean age \pm SD & $44.7 \pm 8.0 y$ & $28.8 \pm 9.8 \mathrm{y}$ \\
\hline Gender (M/F) & $70 / 30$ & $91 / 9$ \\
\hline PD (mm, mean \pm SD) & $4.8 \pm 1.3$ & $<3.0$ \\
\hline CAL (mm, mean \pm SD) & $5.7 \pm 1.6$ & $<3.0$ \\
\hline \multicolumn{2}{|l|}{$P D-$ pocket depth, CAL - clinical attachment loss }
\end{tabular}

\section{MATERIAL AND METHODS}

\section{SAMPLES}

The study was approved by the ethics committee of the Faculty of Dentistry, Universitas Indonesia, and conducted by using samples of DNA that were stored $\left(\right.$ at $-20^{\circ} \mathrm{C}$ ) at the Oral Biology Laboratory of the Faculty of Dentistry [17-19]. The DNA samples were originally extracted from peripheral blood of 100 patients with periodontitis and 100 healthy individuals without periodontitis. Patients were examined by a periodontics (B.S.) and diagnosed as periodontitis based on anamnesis and clinical examination (bleeding on probing [BOP] $(+)$, periodontal pocket depth $\geq 4 \mathrm{~mm}$, and the presence of clinical attachment loss [CAL]) according to the latest classification of periodontal disease [20]. The background information on the subjects is shown in Table 1.

\section{POLYMORPHISM GENOTYPING}

Genetic analysis was conducted by PCR-RFLP, with PCR amplification of the MMP- 8 gene using the following primer sequences: forward 5'-CTG TTG AAG GCC TAG AGC TGC TGC TCC-3' and reverse 5'-CAT CTT CTC TTC AAA CTC TAC CC-3' from Holla (2012), resulting in a 329 bp PCR product. For these reactions, every PCR microtube had a total volume of $20 \mathrm{ml}$, containing $10 \mathrm{ml}$ of KAPA TaqReadyMix PCR with dye (Roche-Kapa Biosystem, Indianapolis, USA; KAPA code, BK1004, Roche Cat. No 07958498001), $0.75 \mathrm{ml}$ forward primer, $0.75 \mathrm{ml}$ reverse primer, $7.75 \mathrm{ml} \mathrm{ddH_{2 }} \mathrm{O}$, and $0.75 \mathrm{ml}$ DNA template. The amplification process consisted of stages of initial denaturation at $95^{\circ} \mathrm{C}$ for $1 \mathrm{~min}$, followed by denaturation at $95^{\circ} \mathrm{C}$ for $30 \mathrm{~s}$, annealing at $55^{\circ} \mathrm{C}$ for $30 \mathrm{~s}$, elongation at $72^{\circ} \mathrm{C}$ for $30 \mathrm{~s}$, which was repeated in 35 cycles; a final extension at $72^{\circ} \mathrm{C}$ was then performed for $5 \mathrm{~min}$. The polymorphism was detected by digesting the PCR product with the DdeI restriction enzyme (Biolabs, Ipswich, England) for 16 hours or overnight at $37^{\circ} \mathrm{C}$ in a water bath. The RFLP product was then inactivated in a thermoblock at $65^{\circ} \mathrm{C}$ for $20 \mathrm{~min}$. Both PCR and RFLP results (fragments) 


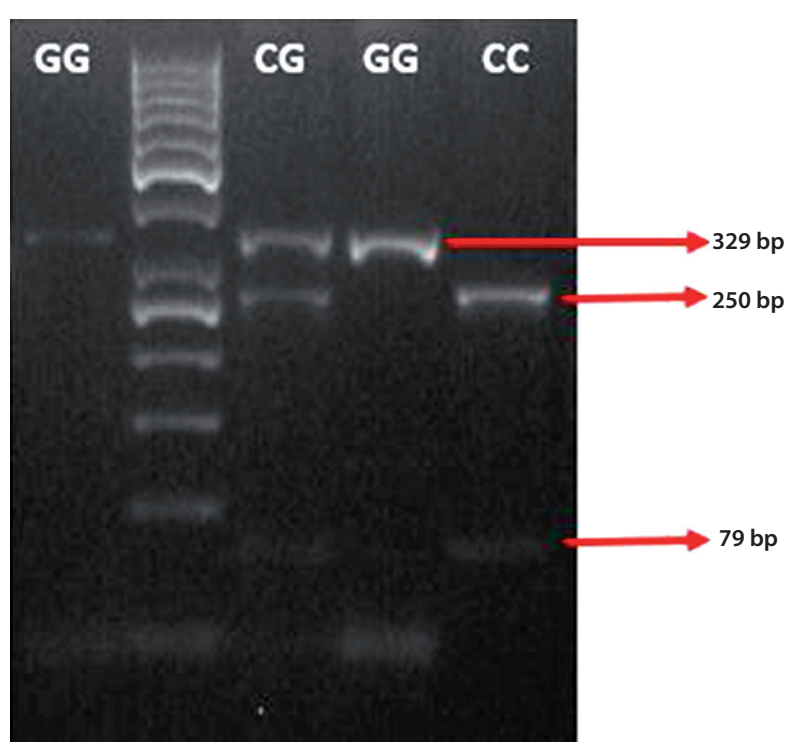

FIGURE 2. The visualization of RFLP products

were visualized using the GelDoc (Bio-Rad, Berkeley, California, USA) after electrophoresis in 3\% agarose gel at $400 \mathrm{~mA} / 80 \mathrm{~V}$ for $65 \mathrm{~min}$. After RFLP, the GG genotype was shown as one $329 \mathrm{bp}$ fragment, because the restriction enzyme DdeI did not recognize any restriction site. The CG genotype, with a restriction site recognized in one allele, appeared as three fragments that were 329 bp, 250 bp, and 79 bp in size. The CC genotype, with recognized restriction sites in both alleles, appeared as two fragments as $250 \mathrm{bp}$ and $79 \mathrm{bp}$.

\section{STATISTICAL ANALYSIS}

Data analysis was conducted using the statistical package SPSS Ver22 (IBM, New York, USA) to analyze the distributions of the $+17 \mathrm{C} / \mathrm{G}$ polymorphism of the $M M P-8$ gene in the periodontitis and control samples. The risk of periodontitis was evaluated using the $\chi^{2}$ test and logistic regression (odds ratios).

\section{RESULTS}

Examples of the visualized 329 bp products after PCR amplification are shown in Figure 1, and examples of the RFLP products are shown in Figure 2. The latter products appeared as a single $329 \mathrm{bp}$ fragment in the case of the homozygote mutant GG genotype (lanes 1 and 4), as two $250 \mathrm{bp}$ and $79 \mathrm{bp}$ fragments in the homozygote CC genotype (wild type, lane 5), or as all three fragments representing the heterozygote genotype CG (lane 3).

Table 2 shows the genotype and allele distributions in the periodontitis and control groups. The wild type CC genotype appeared in $90 \%$ of the periodontitis group samples and in $95 \%$ of the control group samples, and the heterozygotic mutant genotype CG was the least common in both groups. The genotype distributions in both groups were inconsistent with the Hardy-Weinberg equilibrium, which states that allele and genotype frequencies in a population will remain constant from generation to generation in the absence of other evolutionary influences $(p<0.0001)$. The heterozygotic CG genotype appeared much less frequently than the GG genotype, but the number of samples with the CG genotype was too low for analysis. Table 2 demonstrates the corresponding allele distributions in the samples from the periodontitis and control groups.

The results ( $\chi^{2}$ test and odds ratios) showed no significant difference in the proportion of genotypes or alleles between the periodontitis and control samples. The raw odds ratios suggested that the periodontitis group was about a factor of two more likely to present with the polymorphic genotypes (and allele $\mathrm{G}$ ), despite statistical significance.

\section{DISCUSSION}

The presence of MMP-8 is beneficial for normal tissues at low physiological concentrations. However, an increased expression of this gene leads to extracellular matrix degradation during periodontitis, particularly in periodontal tissues containing more than $60 \%$ of type 1 collagen $[11,13]$. The MMP-8 polymorphism can, in principle, lead to a modified expression that could influence this process. The $+17 \mathrm{C} / \mathrm{G}$ polymorphism of MMP- 8 in the exon 1 region results in a shorter form of the protein product, but the outcomes of the present study did not show a statistically significant impact on the risk of periodontitis. This may partly be attributed to the relatively low frequency of the mutant allele ob-

TABLE 2. Genotype and allele distributions in the $+17 \mathrm{C} / \mathrm{G}$ polymorphism of MMP-8

\begin{tabular}{|l|c|c|c|c|}
\hline Type & Periodontitis & Control & P-value & \\
\hline CC & $90(90 \%)$ & $95(95 \%)$ & 0.283 & 2.111 \\
\hline CG & $2(2 \%)$ & $1(1 \%)$ & & $0.695-6.416$ \\
\hline GG & $8(8 \%)$ & $4(4 \%)$ & 0.111 & 2.099 \\
\hline C & $182(91 \%)$ & $191(95.5 \%)$ & $9(4.5 \%)$ & $0.919-4.792$ \\
\hline G & $18(9 \%)$ & & \\
\hline
\end{tabular}


served (Table 2; 9\% in the periodontitis group and $4.5 \%$ in the control group). Therefore, an increase in the sample size might make a difference between the groups, appearing more significant (Table 2). However, the difference could be largely explained by the lower mean age of the subjects in the control group, and possibly by the fairly lower rate of smoking.

There are only a few comparable studies on $+17 \mathrm{C} / \mathrm{G}$ polymorphism of MMP-8, but the results seem to be in general agreement with those in the present study, with no significant associations with chronic [14] or aggressive [15] periodontitis. The previous studies both from Czech and Turkish populations were conducted with 342 periodontitis subjects, 268 control subjects, and 100 periodontitis subjects, 167 control subjects, respectively $[14,15]$. Moreover, none of those studies were conducted among Indonesian subjects. At first, we hypothesized that the origin of the population may influence the polymorphism of the $+17 \mathrm{C} / \mathrm{G}$ polymorphism in MMP-8, but this was not the case here. In the present study, the diagnosis of periodontitis was made based on the latest consensus by the European Federation of Periodontology and the American Academy of Periodontology 2017, where there is no longer chronic or aggressive periodontitis, but rather a scale of staging and grading [20]. In addition, up till now, only few publications have implemented the latest consensus regarding the $+17 \mathrm{C} / \mathrm{G}$ polymorphism in MMP-8.

The distribution of genotypes in the present study was not indicated as consistent with the Hardy-Weinberg equilibrium mainly because the number of samples with the GG genotype was larger than that with the CG genotype. However, the number of samples, particularly of the CG genotype, was insufficient for proper assessment in this respect; hence, the observation was considered as inconclusive.

Of the other known variants of the gene, the -799 $\mathrm{C} / \mathrm{T}$ (rs11225395) polymorphism of MMP-8 has previously been shown to be associated with chronic and aggressive periodontitis $[15,16]$, whereas the $-381 \mathrm{~A} / \mathrm{G}$ (rs1320632) polymorphism of MMP-8 has not been shown to have a significant effect $[14,16]$. The $-799 \mathrm{C} / \mathrm{T}$ polymorphism apparently occurs about four times as often as the two other polymorphisms [12], including the one considered in the present study. This would decrease the sample size needed of the $-799 \mathrm{C} / \mathrm{T}$ polymorphism to demonstrate significance between otherwise similar periodontitis and control groups. Some caution may be due because none of the MMP- 8 polymorphisms has not been implicated in genome-wide association studies (GWAS) on periodontitis [21-25]. However, very few studies on the MMP-8 polymorphism related to periodontitis have been published in the literature; additional studies using larger samples from a wider range of the population are warranted.

Regardless of the significance of MMP- 8 polymorphisms in periodontitis, the involvement of this gene in periodontal tissue destruction can be used as an indicator of the disease in combination with other indicators $[10,11,13]$. A successful combination of the indicators can then provide the risk scores or models for predictive or status assessment of the onset and severity of periodontitis in an individual [26]. Apart from the required technical performance of such combined scores or models, there is also the issue of cost since dental services are generally the fourth most expensive health services in the developed world [2]. With decreasing costs of GWAS and other techniques used to quickly scan the multiple indicators, new cost-effective methods for clinical services may be expected in the future. This would support the development of a path toward more personalized provision of oral health services. The high costs of research and the limited facilities and infrastructure in the laboratory did influence this study. Nevertheless, we hope to conduct additional studies with the help of the government and the private sector in the future for the advancement of research in Indonesia.

\section{CONCLUSIONS}

The results showed no significant association between the $+17 \mathrm{C} / \mathrm{G}$ polymorphism in MMP-8 and the risk of periodontitis among the Indonesian population. No change in the significance is expected even with a considerably larger sample.

\section{ACKNOWLEDGMENT}

This study was supported by the University of Indonesia, grant number NKB-2334/UN2.RST/ HKP.05.00/2020 (EIA).

\section{CONFLICT OF INTEREST}

The authors declare no potential conflicts of interest with respect to the research, authorship, and/or publication of this article.

\section{References}

1. Mattila PT, Niskanen MC, Vehkalahti MM, Nordblad A, Knuuttila MLE. Prevalence and simultaneous occurrence of periodontitis and dental caries. J Clin Periodontol 2010; 37: 962-967.

2. Petersen PE, Bourgeois D, Ogawa H, Estupinan-Day S, Ndiaye C. The global burden of oral diseases and risks to oral health. Bull World Health Org 2005; 83: 661-669.

3. Van der Velden U, Amaliya A, Loos BG, et al. Java project on periodontal diseases: causes of tooth loss in a cohort of untreated individuals. J Clin Periodontol 2015; 42: 824-831.

4. Health Profile 2001 for Healthy Indonesia 2010. Data Centre, Departmentof Health, Republic of Indonesia: Jakarta; 2002 [In Indonesian].

5. Winning L, Patterson CC, Cullen KM, et al. The association between subgingival periodontal pathogens and systemic inflammation. J Clin Periodontol 2015; 42: 799-806. 
6. Laine ML, Crielaard W, Loos BG. Genetic susceptibility to periodontitis. Periodontology 2012; 58: 37-68.

7. Ricci M, Garoia F, Tabarroni C, et al. Association between genetic risks core and periodontitis onset and progression: a pilot study. Arch Oral Biol 2011; 56: 1499-1505.

8. Kinane D, Hart T. Gene and gene polymorphisms associated with periodontal disease. Crit Rev Oral Biol Med 2003; 14: 430-449.

9. Sbardella D, Fasciglione GF, Gioia M, et al. Human matrix metalloproteinases: an ubiquitarian class of enzymes involved in several pathological processes. Mol Aspects Med 2012; 33: 119-208.

10. Dejonckheere E, Vandenbroucke RE, Libert C. Matrix metalloproteinase 8 has a central role in inflammatory disorders and cancer progression. Cytokine Growth Factor Rev 2011; 22: 73-81.

11. Mäntylä P, Stenman M, Kinane D, et al. Monitoring periodontral disease status in smokers and nonsmokers using a gingival crevicular fluid matrix metalloproteinase-8-specific chair-side test. J Periodont Res 2006; 41: 503-512.

12. Wang H, Parry S, Macones G, et al. Functionally significant SNP MMP8 promoter haplotypes and preterm premature rupture of membranes (PPROM). Hum Mol Genet 2004; 13: 2659-2669.

13. Sorsa T, Gursoy UK, Nwhator S, et al. Analysis of matrix metalloproteinases, especially MMP-8, in gingival crevicular fluid, mouthrinse and saliva for monitoring periodontal diseases. Periodontology 2000 2016; 70: 142-163.

14. Izakovicova Holla L, Hrdlickova B, Vokurka J, Fassmann A. Matrix metalloproteinase 8 (MMP8) gene polymorphisms in chronic periodontitis. Arch Oral Biol 2012; 57: 188-196.

15. Emingil G, Han B, Gurkan A, et al. Matrix metalloproteinase (MMP)-8 and tissue inhibitor of MMP-1 (TIMP-1) gene polymorphisms in generalized aggressive periodontitis: gingival crevicular fluid MMP-8 and TIMP-1 levels and outcome of periodontal therapy. J Periodontol 2014; 85: 1070-1080.

16. Chou YH, Ho YP, Lin YC, et al. MMP-8 -799 C $>$ T genetic polymorphism is associated with the susceptibility to chronic and aggressive periodontitis in Taiwanese. J Clin Periodontol 2011; 38: 1078-1084.

17. Tanjaya J, Auerkari EI. IL-1 $\beta$ genetic polimorphism in menopause women as periodontal disease risk factor. J Dent Indones 2011; 18: 1-5.

18. Auerkari EI, Kusdhany LS, Umami SS, Rahardjo TBW, Talbot C. Polymorphism of methylenetetrahydrofolate reductase (A1298C) as a risk factor for osteoporosis in post-menopausal Indonesian women. Asian J Pharm Clin Res 2017; 10: 172-175.

19. Jessica C, Alwadris TT, Prasetyo SR, Puspitawati R, Auerkari EI Associationofinterleukin 8-251 A/T gene polymorphism with periodontitis in Indonesia. J Phys Conf Ser 2018; 1025: 012071.

20. Papapanou P, Sanz M, Buduneli N, et al. Periodontitis: Consensus report of workgroup 2 of the 2017 World Workshop on the Classification of Periodontaland Peri-Implant Diseases and Conditions. J Clin Periodontology 2018; 45 (Suppl 20): S162-S170.

21. Shimizu S, Momozawa Y, Takahashi A, et al. A genome-wide association study of periodontitis in a Japanese population. J Dent Res 2015; 94: 555-561.

22. Divaris K, Monda KL, North KE, et al. Genome-wide association study of periodontal pathogen colonization. J Dent Res 2012; 91: 21S-28S.

23. Schaefer AS, Richter GM, Nothnagel M, et al. COX-2 is associated with periodontitis in Europeans. J Dent Res 2010; 89: 384-388.

24. Teumer A, Holtfreter B, Völker U, et al. Genome-wide association study of chronic periodontitis in a general German population. J Clin Periodontol 2013; 40: 977-985.

25. Hong KW, Shin MS, Ahn YB, Lee HJ, Kim HD. Genomewide association study on chronic periodontitis in Korean population: results from the Yangpyeong health cohort. J Clin Periodontol 2015; 42: 703-710.

26. Korte DL, Kinney J. Personalized medicine: an update of salivary biomarkers for periodontal diseases. Periodontology 2000 2016; 70: 26-37. 